\section{Ultrasonography in psoriatic arthritis: which sites should we scan?}

In psoriatic arthritis (PsA), ultrasonography (US) plays a growing role in the differential diagnosis and in monitoring treatment response. ${ }^{1}$ PsA is a heterogeneous disease with different domains and peculiar sites involved. ${ }^{2}$ Therefore, a dedicated US composite score is needed to monitor disease activity and to identify structural damage progression. A recently published Systematic Literature Review (SLR) identified only two US scores specifically developed for PsA (ie, 5TPD and PsA-Son) and, although these had a good sensitivity to detect inflammation and a good feasibility, they have not been validated in other series. ${ }^{134}$ Recently, the Study Group for US of the Italian Society of Rheumatology promoted the Ultrasound in PSoriatic Arthritis TREAtMent (UPSTREAM) study (registered at ClinicalTrial.gov, NCT03330769). UPSTREAM is a multicentre observational prospective cohort study and it represents the first example of integration between clinical examination and US with the aim to identify predictors of achieving minimal disease activity in patients with PsA starting a new course of therapy.

Our first step, towards the development of a US composite score to be used as an outcome in UPSTREAM, was a qualitative research aimed to define those anatomic sites that are considered relevant by rheumatologists, expert in management of PsA and US. For this purpose, a web-based ranking exercise on the relative relevance of different anatomic structures was done.

Bilaterally, seven entheses, eight joints, 10 tendons with sheath, two tendons without sheath and seven anatomic sites for bursae and soft tissues were identified on the basis of the previous SLR and submitted to vote in the survey. ${ }^{1}$ See table 1 for detailed localisation of each anatomic sites. Within every anatomic structure, a further ranking of sites (eg, for joints: metacarpophalangeal, proximal, distal interphalangeal and metatarsophalangeal joints, wrist, knee) was asked. The between and within weights were calculated as mean of reciprocal rank normalised to $0 \%-100 \%$. In order to balance for the number of items in each category, the final weight was calculated as product of between and within weights multiplied for the number of items and normalised to 0\%-100\%. Final ranking identified those items candidate to be incorporated in the

Table 1 Ranking of the anatomical sites

\begin{tabular}{|c|c|c|c|c|c|c|c|}
\hline Structure & $\begin{array}{l}\text { Between } \\
\text { structure rank }\end{array}$ & $\begin{array}{l}\text { Between } \\
\text { structure weight* }\end{array}$ & Site & $\begin{array}{l}\text { Within } \\
\text { structure rank }\end{array}$ & $\begin{array}{l}\text { Within structure } \\
\text { weight* }\end{array}$ & Overall weight $\dagger$ & $\begin{array}{l}\text { Overall } \\
\text { rank }\end{array}$ \\
\hline \multirow[t]{7}{*}{ Enthesis } & \multirow[t]{7}{*}{1} & \multirow[t]{7}{*}{$27 \%$} & Achilles tendon & 1 & $26 \%$ & $7 \%$ & 1 \\
\hline & & & Patellar ligament (proximal insertion) & 2 & $15 \%$ & $4 \%$ & 7 \\
\hline & & & Patellar ligament (distal insertion) & 3 & $14 \%$ & $4 \%$ & 10 \\
\hline & & & Quadriceps tendon & 4 & $13 \%$ & $4 \%$ & 11 \\
\hline & & & Common extensor tendon (lateral elbow) & 5 & $11 \%$ & $3 \%$ & 13 \\
\hline & & & Plantar aponeurosis & 6 & $11 \%$ & $3 \%$ & 14 \\
\hline & & & Distal insertion of extensor tendon of the finger & 7 & $9 \%$ & $2 \%$ & 20 \\
\hline \multirow[t]{8}{*}{ Joint } & \multirow[t]{8}{*}{2} & \multirow[t]{8}{*}{$26 \%$} & Proximal interphalangeal joint (hand) & 1 & $17 \%$ & $5 \%$ & 2 \\
\hline & & & Metacarpophalangeal joint & 2 & $16 \%$ & $5 \%$ & 3 \\
\hline & & & Wrist joints & 3 & $15 \%$ & $4 \%$ & 5 \\
\hline & & & Knee & 4 & $13 \%$ & $4 \%$ & 8 \\
\hline & & & Distal interphalangeal joint (hand) & 5 & $12 \%$ & $3 \%$ & 12 \\
\hline & & & Metatarsophalangeal joint & 6 & $10 \%$ & $3 \%$ & 16 \\
\hline & & & Ankle joints & 7 & $9 \%$ & $2 \%$ & 19 \\
\hline & & & Elbow joints & 8 & $8 \%$ & $2 \%$ & 21 \\
\hline \multirow{10}{*}{$\begin{array}{l}\text { Tendon with } \\
\text { sheath }\end{array}$} & \multirow[t]{10}{*}{3} & \multirow[t]{10}{*}{$18 \%$} & Flexor tendon of the digit & 1 & $17 \%$ & $4 \%$ & 4 \\
\hline & & & Compartment of extensor tendons (wrist) & 2 & $16 \%$ & $4 \%$ & 6 \\
\hline & & & Posterior tibialis tendon & 3 & $11 \%$ & $3 \%$ & 15 \\
\hline & & & Anterior tibialis tendon & 4 & $10 \%$ & $3 \%$ & 17 \\
\hline & & & Peroneal tendons & 5 & $10 \%$ & $3 \%$ & 18 \\
\hline & & & Extensor hallucis longus tendon & 6 & $8 \%$ & $2 \%$ & 22 \\
\hline & & & Extensor digitorum longus tendon & 7 & $8 \%$ & $2 \%$ & 25 \\
\hline & & & Flexor digitorum longus tendon & 8 & $7 \%$ & $2 \%$ & 27 \\
\hline & & & Flexor hallucis longus tendon & 9 & $7 \%$ & $2 \%$ & 29 \\
\hline & & & Flexor tendons of the toes & 10 & $6 \%$ & $2 \%$ & 30 \\
\hline \multirow{2}{*}{$\begin{array}{l}\text { Tendon without } \\
\text { sheath }\end{array}$} & \multirow{2}{*}{4} & \multirow[t]{2}{*}{$16 \%$} & Extensor tendons of the digits & 1 & $63 \%$ & $2 \%$ & 24 \\
\hline & & & Extensor tendons of the toes & 2 & $37 \%$ & $1 \%$ & 34 \\
\hline \multirow{7}{*}{$\begin{array}{l}\text { Bursa and } \\
\text { subcutaneous } \\
\text { tissue }\end{array}$} & \multirow[t]{7}{*}{5} & \multirow[t]{7}{*}{$14 \%$} & Achilles bursa & 1 & $26 \%$ & $4 \%$ & 9 \\
\hline & & & Olecranic bursa & 2 & $15 \%$ & $2 \%$ & 23 \\
\hline & & & Semimembranosus and gastrocnemius bursa & 3 & $15 \%$ & $2 \%$ & 26 \\
\hline & & & Soft tissue oedema of the hands & 4 & $14 \%$ & $2 \%$ & 28 \\
\hline & & & Medial malleolar bursa & 5 & $11 \%$ & $2 \%$ & 31 \\
\hline & & & Lateral malleolar bursa & 6 & $10 \%$ & $1 \%$ & 32 \\
\hline & & & Soft tissue oedema of the toes & 7 & $10 \%$ & $1 \%$ & 33 \\
\hline
\end{tabular}

The sites included in ultrasound scanning protocol of the Ultrasound in PSoriatic Arthritis TREAtMent study are marked in green in the 'rank' column.

${ }^{*}$ Calculated as inverse of mean rank normalised from $0 \%$ to $100 \%$.

†Calculated as product of structure weights ${ }^{*}$ site weight ${ }^{*}$ number of sites within structure and normalised to $0 \%-100 \%$. 
scanning US protocol of the UPSTREAM study. To satisfy content validity requirement, at least one item per anatomic structure was included. Twenty rheumatologists, with experience in musculoskeletal US and in the management of PsA, participated in the web exercise. The anatomic structures with a better ranking were: entheses, joints, tendons with sheath, tendons without sheath and ultimately soft tissues and bursae. Considering the overall weight for each site, enthesis of Achilles tendon achieved the best results. The full results are reported in table 1 . Through this web-based exercise, we identified the anatomic sites considered useful in revealing typical US changes of PsA and they will be incorporated in the US protocol of the UPSTREAM study. This is a first essential step to assess the content of a simplified US score that will encompass both joint and extra-articular structures, most informative in the US evaluation of PsA.

\section{Alen Zabotti, ${ }^{1}$ Matteo Piga, ${ }^{2}$ Marco Canzoni, ${ }^{3}$ Garifallia Sakellariou, ${ }^{4}$ Annamaria lagnocco, ${ }^{5}$ Carlo Alberto Scirè, ${ }^{6,7}$ on behalf of the UPSTREAM study group.}

'Department of Medical and Biological Sciences, Rheumatology Clinic, University Hospital 'Santa Maria della Misericordia', Udine, Italy

${ }^{2}$ Chair of Rheumatology and Rheumatology Unit, University Clinic and AOU of Cagliari, Cagliari, Italy

${ }^{3}$ Local Health Unit (ASL) Rome-1, Rome-4, Viterbo, Italy

${ }^{4}$ Division of Rheumatology, IRCSS Policlinico San Matteo Foundation, University of Pavia, Pavia, Italy

${ }^{5}$ Department of Medical and Biological Sciences, University of Turin, Torino, Italy

${ }^{6}$ Department of Medical Sciences, Section of Rheumatology, University of Ferrara, Ferrara, Italy

${ }^{7}$ Epidemiology Unit, Italian Society of Rheumatology (SIR), Milan, Italy

Correspondence to Dr Alen Zabotti, Department of Medical and Biological Sciences, University Hospital, 'Santa Maria della Misericordia', Udine 33100, Italy; zabottialen@gmail.com

\section{Handling editor Josef S Smolen}

Collaborators Antonella Adinolfi, Irene Azzolin, Francesca Bandinelli, Alberto Batticciotto, Nicola Boffini, Alessandra Bortoluzzi, Greta Carrara, Francesco Paolo Cavatorta, Giovanni Cagnotto, Marta Caprioli, Michele Colaci, Orazio De Lucia, Andrea Delle Sedie, Valentina Denaro, Andrea Di Matteo, Valentina Di Sabatino,
Oscar Massimiliano Epis, Ariela Hoxha, Ilaria Farina, Giuseppe Germanò, Georgios Filippou, Emilio Filippucci, Maria Cristina Focherini, Alessandra Gabba, Luca Idolazzi, Giuliana Maria Concetta La Paglia, Filippo Luccioli, Pierluigi Macchioni, Mirco Magnani, Marco Massarotti, Claudio Mastaglio, Luca Navarini, Simone Parisi, Andrea Picchianti Diamanti, Valentina Picerno, Marco Piras, Francesco Porta, Niccolò Possemato, Immacolata Prevete, Bernd Raffeiner, Roberta Ramonda, Viviana Ravagnani, Daniela Rossi, Silvia Rossi, Palma Scolieri, Gianluca Santoboni, Crescenzio Scioscia, Riccardo Terenzi, Ilaria Tinazzi, Carmela Toscano, Carlo Venditti, Alessandro Volpe, Gentiana Vukatana, Giovanni Zanframundo.

Funding This research received no specific grant from any funding agency in the public, commercial or not-for-profit sectors.

Competing interests None declared.

Patient consent Not required.

Provenance and peer review Not commissioned; externally peer reviewed.

(c) Article author(s) (or their employer(s) unless otherwise stated in the text of the article) 2018. All rights reserved. No commercial use is permitted unless otherwise expressly granted.

\section{Check for updates}

To cite Zabotti A, Piga M, Canzoni M, et al. Ann Rheum Dis Epub ahead of print: [please include Day Month Year]. doi:10.1136/annrheumdis-2018-213025

Received 15 January 2018

Revised 19 February 2018

Accepted 20 February 2018

Ann Rheum Dis 2018;0:1-2. doi:10.1136/annrheumdis-2018-213025

\section{REFERENCES}

1 Zabotti A, Bandinelli F, Batticciotto A, et al. Musculoskeletal ultrasonography for psoriatic arthritis and psoriasis patients: a systematic literature review. Rheumatology 2017;56:1518-1532.

2 McGonagle D, Lories RJ, Tan AL, et al. The concept of a "synovio-entheseal complex" and its implications for understanding joint inflammation and damage in psoriatic arthritis and beyond. Arthritis Rheum 2007;56:2482-91.

3 Gutierrez M, Di Geso L, Salaffi F, et al. Development of a preliminary US power Doppler composite score for monitoring treatment in PsA. Rheumatology 2012;51:1261-8.

4 Ficjan A, Husic R, Gretler J, et al. Ultrasound composite scores for the assessment of inflammatory and structural pathologies in Psoriatic Arthritis (PsASon-Score). Arthritis Res Ther 2014;16:476. 


\section{U Ultrasonography in psoriatic arthritis: which sites should we scan?}

Alen Zabotti, Matteo Piga, Marco Canzoni, Garifallia Sakellariou, Annamaria lagnocco and Carlo Alberto Scirè

Ann Rheum Dis published online March 9, 2018

Updated information and services can be found at:

http://ard.bmj.com/content/early/2018/03/09/annrheumdis-2018-2130 25

These include:

References This article cites 4 articles, 0 of which you can access for free at: http://ard.bmj.com/content/early/2018/03/09/annrheumdis-2018-2130 25\#ref-list-1

Email alerting

Receive free email alerts when new articles cite this article. Sign up in the service box at the top right corner of the online article.

\section{Notes}

To request permissions go to:

http://group.bmj.com/group/rights-licensing/permissions

To order reprints go to:

http://journals.bmj.com/cgi/reprintform

To subscribe to BMJ go to:

http://group.bmj.com/subscribe/ 